\title{
Synthesis of 5-Oxy-camphor.
}

By

\author{
Kunijiro TaKeuchi. \\ (Received January 8, 1934)
}

According to Y. Asahina and M. Ishidate ${ }^{(1)}$ 5-oxy-camphor is a chief component of "Campherol"(2) which is obtained from the urine of dogs administered with camphor. The present author has tried to prepare it synthetically.

L. Ruzicka and Liebi obtained isoborneol ${ }^{(3)}$ according to Bertram and Walbaum's method by acetylating $a$-pericyclocamphane with glacial acetic acid and sulphuric acid and then saponifying the acetylated product as shown in the following scheme:

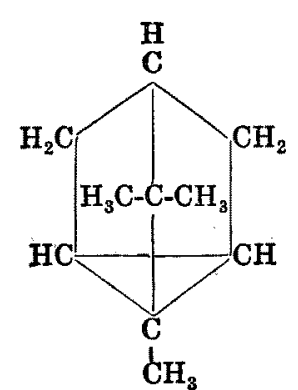

a-Pericyclocamphane
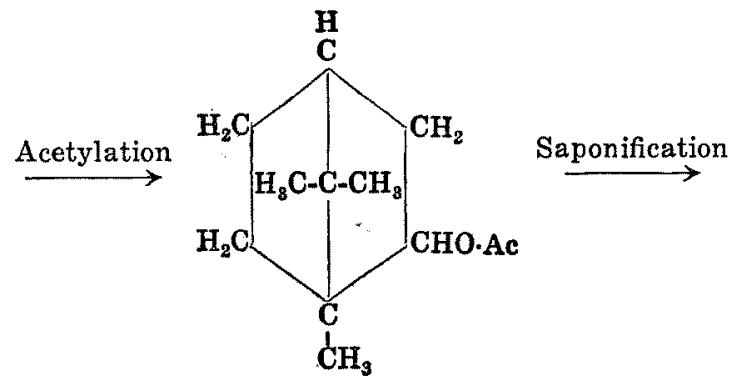

Acetyl-isoborneol<smiles>CC1(C)C2CC3CCC1(C)C3C2</smiles>

Isoborneol

Applying this method to $\beta$-pericyclocamphanone, and using trichloracetic acid in place of glacial acetic acid, the present author succeeded in synthesizing 5-oxy-camphor which was identical with the one isolated from dog's urine 
according to the method of Asahina and co-workers. The starting material, $\beta$-pericyclocamphanone, was prepared by heating diazocamphor at $140^{\circ} \mathrm{C}$. There are two methods for the preparation of diazocamphor: one is amino camphor-method, ${ }^{(4)}$ and the other is camphorhydrazone-method. ${ }^{(5)}$ These methods are briefly stated in the following schemes.

[A] Aminocamphor-method.<smiles>CC1(C)[C@H]2CC[C@@]1(C)C(=O)C2</smiles>

Camphor

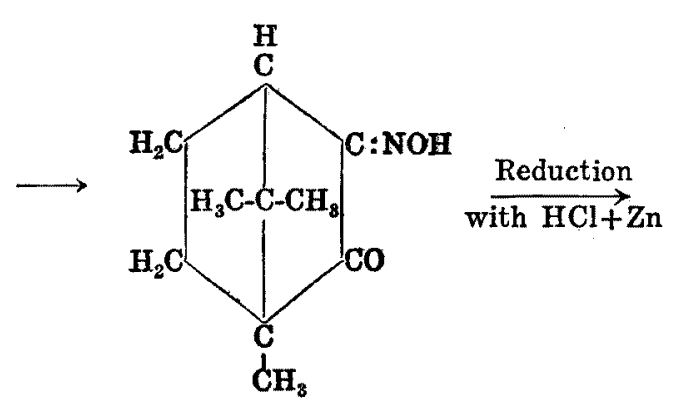

Isonitrosocamphor<smiles>CC1C2CCC(C)(CC2=O)C1N</smiles>

Aminocamphor

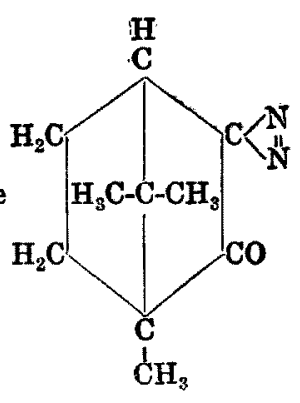

Diazocamphor

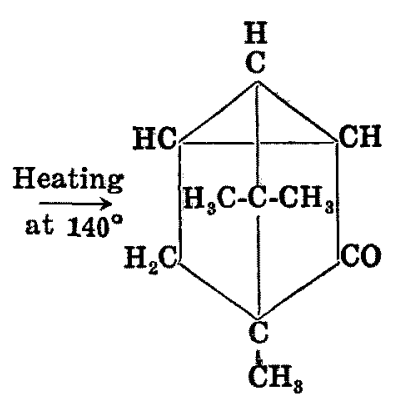

$\beta$-Pericyclocamphanone

[B] Camphorhydrazone method.

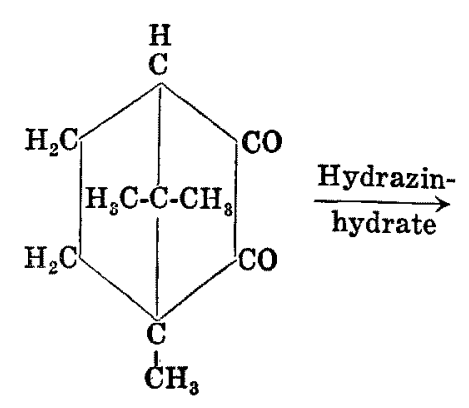

Camphorquinone

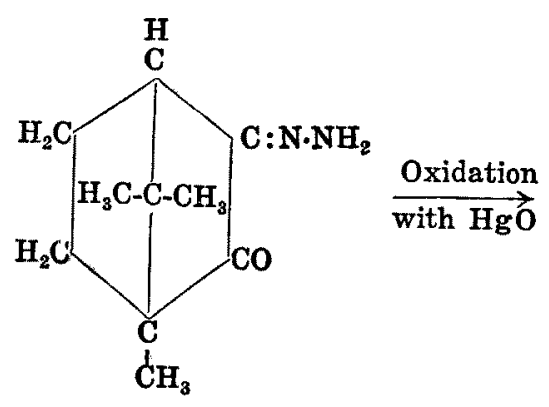

Camphorquinonemonohydrazone 
<smiles>CC12CCC(C3N=N3)C(C)(C1)C2=O</smiles>

Diazocamphor<smiles>CC12CC3C4CC(C)(C3C1)C42</smiles>

$\beta$-Pericyclocamphanone

5-Oxy-camphor from $\beta$-pericyclocamphanone was prepared as follows :

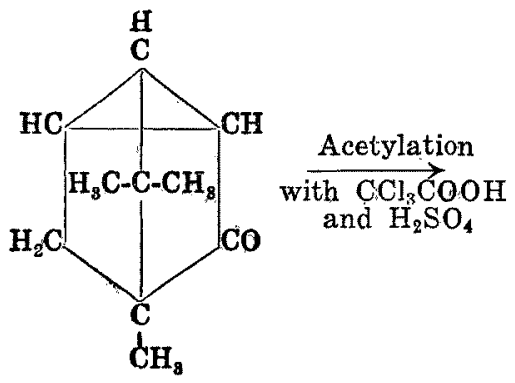

$\beta$-Pericyclocamphanone

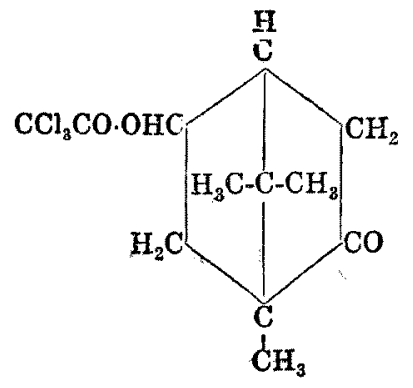

5-Oxy-camphor-trichloracetic acid ester

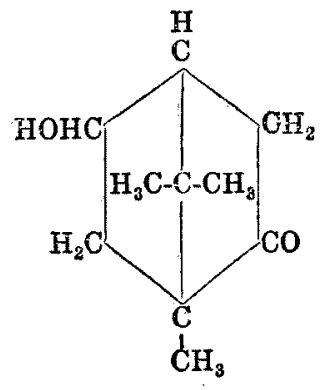

5-Oxy-camphor 


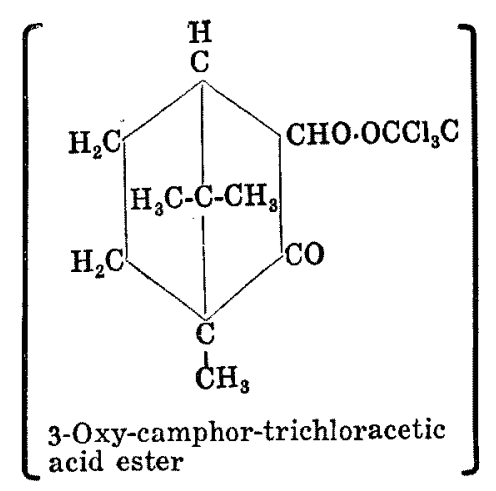

\section{Experimental.}

Part I. Preparation of $\beta$-Pericyclocamphanone.

A. Aminocamphor-method.

(1) Isonitrosocamphor.

Five hundred grams of commercial camphor (m. p. $=176 \sim 7^{\circ} \mathrm{C},[a]_{\mathrm{D}}^{18}=+$ $46.99^{\circ}$ in abs. alc. $\mathrm{c}=7.08$ ) was dissolved in $1250 \mathrm{c} . \mathrm{c}$. dry ether in a flask. to which $74 \mathrm{~g}$ metallic sodium was added. Cooling the flask with ice at 10 $\sim 15^{\circ} \mathrm{C}$, dry methyl nitrite gas (which was generated by dropping a solution of $230 \mathrm{~g}$ sodium nitrite in $500 \mathrm{ccc}$. water into the mixture of 400 c.c. water, 120 c.c. methyl alcohol, and 90 c.c. concentrated sulphuric acid) was passed into the flask. After several hours, the etherial solution was shaken with water and the aqueous solution of the sodium isonitrosocamphor was washed with ether to remove borneol and the excess of camphor, and then neutralized with dilute hydrochloric acid. Isonitrosocamphor thus obtained was recrystallized from dilute methyl alcohol ; prismatic crystals; yield : $167 \mathrm{~g}$.

$$
\begin{aligned}
& \text { m. p. }=151 \sim 152^{\circ} \mathrm{C} \text { (uncorr.) } \\
& {[a]_{D}^{24}=+200^{\circ} \text { in abs. alc. }(c=3.90)}
\end{aligned}
$$

(2) Aminocamphor sulphate.

One hundred grams of isonitrosocamphor was dissolved in 1,000 c.c. $50 \%$ hydrochloric acid and reduced with $200 \mathrm{~g}$ zinc dust. Sufficient sodium hydroxide solution was added and the oily aminocamphor separated thereby was then dissolved in ether and added with dilute sulphuric acid drop by drop until the aqueous solution became slightly acid. On evaporating the solution, aminocamphor sulphate separated out as white lustrous crystals. Yield : about $65 \mathrm{~g}$;

$$
\begin{aligned}
& \mathrm{m} \cdot \mathrm{p} .=213 \sim 214^{\circ} \mathrm{C} \text { (uncorr.) } \\
& {[a]_{\mathrm{D}}^{18}=+9.51^{\circ} \text { in water }(c=4.51)}
\end{aligned}
$$


(3) Diazocamphor.

By adding sodium nitrite and dilute sulphuric acid into the aqueous solution of aminocamphor sulphate, cooling by means of ice, diazocamphor separated out as yellow crystals. It was then purified from petroleum ether. Yield: $78 \mathrm{~g}$ pure diazocamphor from $210 \mathrm{~g}$ aminocamphor sulphate;

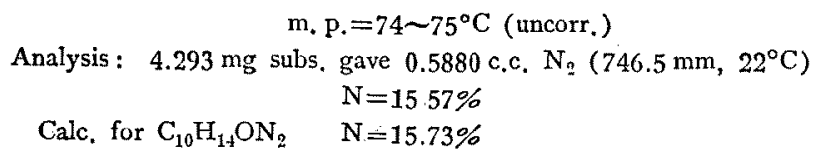

(4) $\beta$-Pericyclocamphanone.

$\beta$-Pericyclocamphanone was obtained by heating, a small portion at a time, the mixture of $10 \mathrm{~g}$ finely powdered crystals of diazocamphor and $30 \mathrm{~g}$ dried copper powder in a retort at $140^{\circ} \mathrm{C}$. It was purified by sublimation and subsequently recrystallized from petroleum ether. Yield: $8.5 \mathrm{~g}$;

$$
\begin{gathered}
\text { m. p. }=167^{\circ} \mathrm{C} \text { (uncorr.) } \\
{[a]_{\mathrm{D}}^{18}=+63.35^{\circ} \text { in abs. alc. }(c=1.61 \text { ) }} \\
\text { Analysis : } 3.710 \mathrm{mg} \text { subs. gave } 10.785 \mathrm{mg} \mathrm{CO}, 3.120 \mathrm{mg} \mathrm{H} \mathrm{H}_{2} \mathrm{O} ;
\end{gathered}
$$$$
\begin{array}{lll}
\text { Calc, for } \mathrm{C}_{10} \mathrm{H}_{40} \mathrm{O} & \mathrm{C}=79.28 \% & \mathrm{H}=9.40 \% \\
& \mathrm{C}=79.92 \% & \mathrm{H}=9.42 \%
\end{array}
$$

B. Camphorhydrazone-method.

\section{(1) Camphormonohydrazone.}

Twelve grams of hydrazine hydrate was gradually added, small portion at a time, into the boiling alcoholic $(40 \mathrm{c.c}$.) solution of camphorquinone $(25 \mathrm{~g})$ (Kahlbaum's preparation, m. p. $=195 \sim 196^{\circ} \mathrm{C},[\alpha]_{\mathrm{D}}^{20}-80.82^{\circ}$ in benzol, $c=1.69$ ). The hydrazone separated on cooling was recrystallized from alcohol. Yield: $20.3 \mathrm{~g}$;

\section{(2) Diazocamphor.}

$$
\begin{gathered}
\text { Analysis : } 4.716 \mathrm{mg} \text { subs. gave } 0.6331 \text { c.c. } \mathrm{N}_{2}\left(762 \mathrm{~mm}, 19^{\circ} \mathrm{C}\right) \\
\mathrm{N}=15.73 \% \\
\text { Calc. for } \mathrm{C}_{10} \mathrm{H}_{16} \mathrm{ON}_{2} \quad \mathrm{~N}=1.5 .55 \%
\end{gathered}
$$

Thirteen and eight-tenths grams of camphormonohydrazone was dissolved in 100 c.c. hot benzol and then added $22 \mathrm{~g}$ yellow mercuric oxide, and the mixture was heated on a water bath for ten hours. Diazocamphor thus separated out was purified from petroleum ether. Yield: $10.3 \mathrm{~g}$ :

$$
\begin{gathered}
\mathrm{m}, \mathrm{p} .=72^{\circ} \mathrm{C} \text { (uncoor.) } \\
\text { Analysis : } 2.642 \mathrm{mg} \text { subs. gave } 0.3420 \text { c.c. } \mathrm{N}_{2}\left(763 \mathrm{~mm}, 13.2^{\circ} \mathrm{C}\right. \text { ) } \\
\mathrm{N}=15.50 \% \\
\text { Calc. for } \mathrm{C}_{10} \mathrm{H}_{14} \mathrm{ON}_{2} \quad \mathrm{~N}=15.73 \%
\end{gathered}
$$

(3) $\beta$-Pericyclocamphanone.

$\beta$-Pericyclocamphanone was prepared from the diazocamphor in the same manner as described in the previous experiment [A]. (4); 


$$
\begin{aligned}
& \qquad \mathrm{m}, \mathrm{p},=167^{\circ} \mathrm{C} \\
& {[a]_{\mathrm{D}}^{17}=+63.37^{\circ} \text { in abs, alc. }(c=3.66)} \\
& \text { Analysis : } 2.849 \mathrm{mg} \text { subs, gave } 8.240 \mathrm{mg} \quad \mathrm{CO}_{2}, 2.357 \mathrm{mg} \mathrm{H} \mathrm{H}_{2} \mathrm{O} ; \\
& \mathrm{C}=78.9 \% \quad \mathrm{H}=9.26 \% \\
& \text { Calc. for } \mathrm{C}_{10} \mathrm{C}_{14} \mathrm{O} \quad \mathrm{C}=79.92 \% \quad \mathrm{II}=9.42 \%
\end{aligned}
$$

Part II. Preparation of 5-Oxy-camphor.

\section{(1) Acetylation product of $\beta$-pericyclocamphanone.}

Five grams of $\beta$-pericyclocamphanone, $20 \mathrm{~g}$ trichloracetic acid and $0.5 \mathrm{~g}$ concentrated sulphuric acid were mixed in a flask provided with air-cooler, and heated in oil-bath at $150 \sim 160^{\circ} \mathrm{C}$ for ten hours. After cooling, the resinous mass was extracted with ether and the etherial solution was successively washed with water, with $5 \%$ sodium carbonate solution, and again with water, After evaporating the ether off, the residue was subjected to steam distillation in order to remove the excess of $\beta$-pericyclocamphanone. The residue was then extracted with ether, and the etherial solution was treated with animal charcoal, and succesively dehydrated, evaporated and distilled. The distillate thus obtained became pasty on keeping in ice-box for several days. Yield: $1 \mathrm{~g}$;

$$
\begin{aligned}
& \text { b. } \mathrm{p}=4 \mathrm{~mm} 140 \sim 145^{\circ} \mathrm{C} \text { (uncorr.) } \\
& {[a]_{\mathrm{D}}^{17}=+9.30^{\circ} \text { in abs, alc, }(c=3.44)}
\end{aligned}
$$

Analysis : $3.606 \mathrm{mg}$ subs, gave $6.270 \mathrm{mg} \mathrm{CO}, 1.736 \mathrm{mg} \mathrm{H}_{2} \mathrm{O}$;

$$
\mathrm{C}=47.42 \% \mathrm{H}=5.3 \%
$$

Calc. for $\mathrm{C}_{12} \mathrm{H}_{35} \mathrm{O}_{3} \mathrm{Cl}_{3} \quad \mathrm{C}=45.93 \% \quad \mathrm{H}=4.7 \%$

$10.34 \mathrm{mg}$ subs, gave $12.43 \mathrm{mg} \mathrm{AgCl}$;

$9.97 "$ " " $12.16 "$ "

$$
\begin{aligned}
\mathrm{Cl} & =29.74 \% \\
\prime \prime & =30.17 \%
\end{aligned}
$$

Calc. for $\mathrm{C}_{12} \mathrm{H}_{15} \mathrm{O}_{3} \mathrm{Cl}_{3} \quad \mathrm{Cl}=33.9 \%$

Trichloracetic acid ester of 5-oxy-camphor from dog's urine was prepared by the same way as mentioned above.

One half gram $f$ 5-oxy-camphor and $1 \mathrm{~g}$ trichloracetic acid were placed in a flask with air.cooler, and heated in oil-bath at $150^{\circ} \mathrm{C}$ for two hours. The reaction product was then subjected to steam distillation and the residue was extracted with ether, washed with animal charcoal. After dehydration and evaporation, it was kept in a vacuum desiccator for several days, and analyzed as follows;

$$
[a]_{D}^{16}=+26.60^{\circ} \text { in abs. alc. }(c=1.84)
$$

Analysis: $10.18 \mathrm{mg}$ subs, gave $12.38 \mathrm{mg} \mathrm{AgCl}$

$$
\begin{array}{cl}
10.06 \prime \prime \prime \prime & 12.22 " \\
& \mathrm{Cl}=30.09 \% \\
& \prime=30.03 \% \\
\text { Calc. for } \mathrm{C}_{12} \mathrm{H}_{15} \mathrm{O}_{3} \mathrm{Cl}_{3} & \mathrm{Cl}=33.39 \%
\end{array}
$$

(2) 5-Oxy-camphor.

Two grams of acetylation product of $\beta$-pericyclocamphanone mentioned 
above were dissolved in $94 \%$ alcohol containing $5 \mathrm{~g}$ potassium hydroxide, and heated in a flask, fitted with reverted cooler, on water-bath for two hours. After cooling, the mixture was neutralized by passing $\mathrm{CO}_{2}$ gas and then distilled to remove the alcohol. The residue was then extracted with ether, and after washing the etherial solution with water, it was dehydrated and evaporated. On recrystallization from hot ligroin (b. p. $=80 \sim 120^{\circ} \mathrm{C}$ ), it formed nice characteristic crystals (Photo. 2) which were colourless, odourless, and adhesive as camphor; hardly soluble in cold ligroin, but easily soluble in alcohol, ether, benzol and acetic acid. Yield : $0.5 \mathrm{~g}$;

$$
\begin{aligned}
& \text { m. } \mathrm{P}=222 \sim 222.5^{\circ} \mathrm{C} \text { (uncorr.) } \\
& {[a]_{\mathrm{D}}^{17}=+42.7^{\circ} \text { in abs. alc. }(c=0.34)} \\
& {[a]_{\mathrm{D}}^{18}=+43.5^{\circ} \text { in abs, alc. }(c=2.09)}
\end{aligned}
$$

Mixed with the specimen of 5-oxy-camphor (m. p. $=222^{\circ} \mathrm{C},[\alpha]_{\mathrm{D}}^{24}=+43.9^{(6)}$ Photo. 1) prepared from dog's urine, no depression of melting point was observed.

Molecular weight (freezing point depression method);

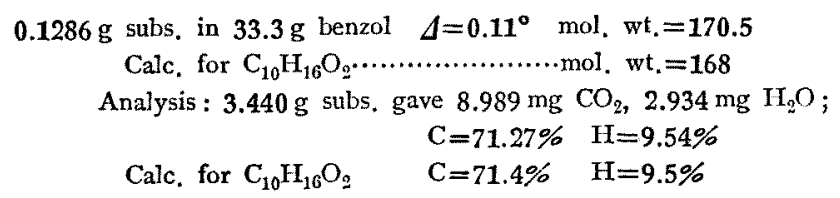

Semicarbazone of the above synthetic 5-oxy-camphor was prepared in the usual way;

$$
\begin{gathered}
\mathrm{m} . \mathrm{p} .=232 \sim 3^{\circ} \mathrm{C} \\
\text { Analysis : } 3.979 \mathrm{mg} \text { subs. gave } 0.6497 \text { c.c. } \mathrm{N}_{2}\left(753 \mathrm{~mm}, 15.0^{\circ} \mathrm{C}\right) \\
\mathrm{N}=19.18 \% \\
\text { Calc. for } \mathrm{C}_{11} \mathrm{H}_{19} \mathrm{O}_{2} \mathrm{~N}_{3} \quad \mathrm{~N}=18.6 \%
\end{gathered}
$$

Acetyl-5-oxy-camphor was prepared by heating $1 \mathrm{~g}$ of the above 5-oxycamphor and 1 c.c. acetic anhydride on oil-bath at $140^{\circ} \mathrm{C}$ for two hours. The excess of acetic anhydride was decomposed with water, and the reaction product was extracted with ether. The etherial solution was washed with $5 \%$ sodium carbonate solution, evaporated and distilled;

$$
\begin{aligned}
& \text { b. } \mathrm{P} .=23 \mathrm{~mm} 145 \sim 147^{\circ} \mathrm{C} \text { (uncorr.) } \\
& {[a]_{\mathrm{D}}^{19}=+26.27 \text { in abs, alc. }(c=1.18)}
\end{aligned}
$$

Analysis : $4.079 \mathrm{mg}$ subs. gave $10.105 \mathrm{mg} \mathrm{CO}_{2}, 3.036 \mathrm{mg} \mathrm{H}_{2} \mathrm{O}$;

$$
\begin{array}{llll} 
& \mathrm{C}=67.57 \% & \mathrm{H}=8.33 \% \\
\text { Calc. for } \mathrm{C}_{12} \mathrm{H}_{18} & \mathrm{O}_{3} & \mathrm{C}=68.6 \% & \mathrm{H}=8.6 \%
\end{array}
$$

The preparation of synthetic 5-oxy-camphor agreed with that obtained from dog's urine by Y. Asahina and M. Ishidate as shown in the table below: 


\begin{tabular}{|c|c|c|}
\hline & Y. Asahina and M. Ishidate & The present author \\
\hline 5-Oxy-camphor & $\begin{array}{l}\mathrm{m} \cdot \mathrm{p} .=222^{\circ}\left(217 \sim 8^{\circ}\right) \mathrm{C} \\
{[a]_{\mathrm{D}}^{30}=+43.2^{\circ}\left(41.3^{\circ}\right) \text { in alc. }} \\
\mathrm{C}=71.04 \% \\
\mathrm{II}=9.6 \%\end{array}$ & $\begin{array}{l}\mathrm{m}, \mathrm{p} .=222 \sim 222.5^{\circ} \mathrm{C} \\
{[a]_{D}^{18.0}=+42.7 \sim 43.5^{\circ} \text { in alc. }} \\
\quad \mathrm{C}=71.27 \% \\
\mathrm{H}=9.54 \%\end{array}$ \\
\hline $\begin{array}{l}\text { 5-Oxy-camphor- } \\
\text { semicarbazone }\end{array}$ & $\begin{array}{c}\text { m. p. }=233 \sim 5^{\circ} \mathrm{C} \\
\mathrm{N}=19.1 \%\end{array}$ & $\begin{array}{c}\mathrm{m} \cdot \mathrm{p} .=232 \sim 3^{\circ} \mathrm{C} \\
\mathrm{N}=19.1 \%\end{array}$ \\
\hline $\begin{array}{l}\text { Acetyl-5-oxy- } \\
\text { camphor }\end{array}$ & $\begin{array}{l}\text { b.p. }=27 \mathrm{~mm} 159 \sim 60^{\circ} \mathrm{C} \\
{[a]_{D}^{20}=+24.8 \text { in alc. }} \\
C=68.58 \% \\
H=9.00 \%\end{array}$ & $\begin{array}{l}\text { b. p. }=23 \mathrm{~mm} 145 \sim 7^{\circ} \mathrm{C} \\
{[a]_{\mathrm{D}}^{19}=+26.27 \text { in alc. }} \\
\mathrm{C}=67.57 \% \\
\mathrm{H}=8.33 \%\end{array}$ \\
\hline
\end{tabular}

After all, starting with $d$-camphor, the author has succeded in synthesizing 5-oxy-camphor which was identical both in physical and chemical properties with the preparation isolated from dog's urine. Theoretically, however, two stereoisomers of 5-oxy-camphor can be produced from $d$-camphor as shown in the following scheme:

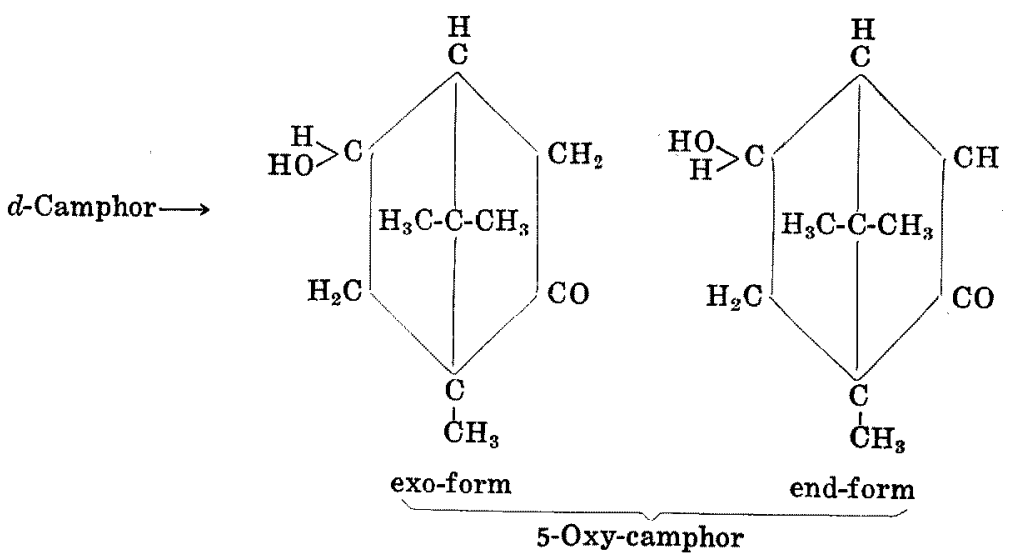

Further investigations on this subject are still being carried on and the reports will be published in near future.

The author whishes to express his sincere thanks to Professors U. Suzuki and T. Yabuta for their kind guidances throughout this work, and also to Dr. Y. Sahashi for his kihd advices. For analyses, the author is indebted to Mr. S. Funahashi and Miss S. Matsumoto. 


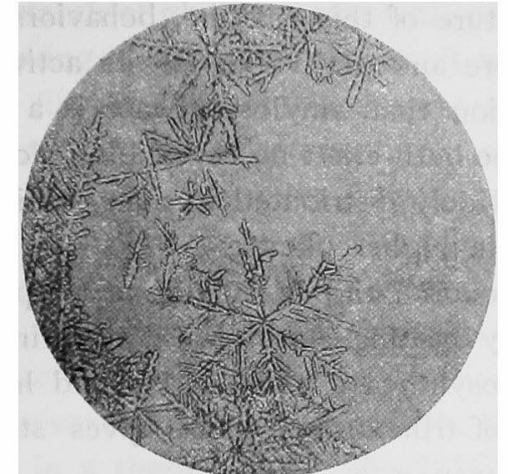

Photo. 1-5-Oxy-camphor from dog's urine.

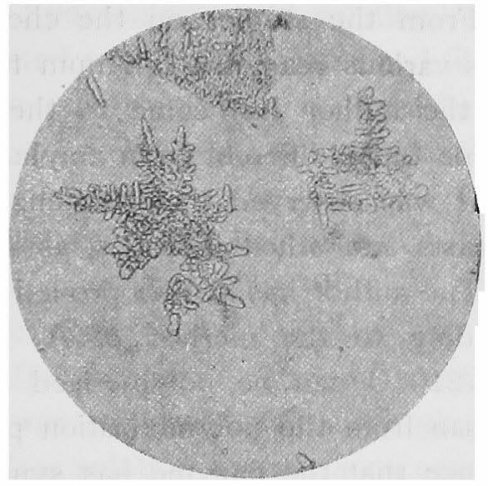

Photo. 2-Synthetic 5-oxy-camphor.

\title{
Literature.
}

(1) Y. Asahina and M. Ishidate: J. Pharm. Soc. Japan, 48, 77, (1928).

(2) Schmiedeberg and Meyer: Z. physiol. Chem., 3, 422, 1.

(3) I. Ruzicka and Liebi : Helv., 9, 144, (1926).

(4) R. Schff: Ber., 14, 1373, (1881).

A. Angeli : Ber., 28, 819, (1893).

(5) J. Bredt and W. Holz: Z. prak. Chem., 2, 133, (1917).

(6) K. Takeuchi and Y. Sahashi : Sc. Pap. I. P. C. R., 22, 66, (1933).

\section{Studies on Amylosynthease.}

\author{
By \\ Toyosaku Mrnagawa. \\ (Agricultural Chemical Laboratory, Tokyo Imperial University, Komaba, Tokyo.) \\ (Received February 8, 1934.)
}

\section{Introduction.}

The existence of an enzyme in the autolysed extract of brewer's yeast which has the power of polymerising achroodextrines into higher ones was first observed by S. Nishimura ${ }^{(1)}$ in 1930 and the name "Amylosynthease" was given to it. The present author continued the studies on this subject, at first in association with the above named author and afterwards independently and succeeded in preparing the enzyme quite free from amylase, which occurs always associated with the former and interferes the polymerisation process, exerting the reverse reaction. 